\title{
PENGEMBANGAN LEMBAR KERJA PESERTA DIDIK BERDASARKAN IDENTIFIKASI KEANEKARAGAMAN CAPUNG DI PERSAWAHAN DESA TABEAK KAUK KABUPATEN LEBONG
}

\author{
Elza Anggun Yunasiska ${ }^{1 *}$, Irwandi Ansori ${ }^{1}$, Abdul Rahman $^{1}$ \\ ${ }^{1}$ Program Studi Pendidikan Biologi, Fakultas Keguruan dan Ilmu Pendidikan, Universitas Bengkulu \\ E-mail : elzaanggunys24@gmail.com
}

\begin{abstract}
Abstrak
Penelitian ini bertujuan untuk mengembangkan Lembar Kerja Peserta Didik (LKPD) yang berdasarkan identifikasi jenis capung yang terdapat di area persawahan Desa Tabeak Kauk. Jenis penelitian ini adalah Penelitian dan Pengembangan menggunakan model pengembangan Sugiyono. Langkahlangkah dalam penelitian ini terdiri dari potensi masalah, pengumpulan data, desain produk, validasi desain, revisi desain, uji coba dan revisi produk. Uji coba skala terbatas dilakukan pada peserta didik kelas X SMAN 3 Kabupaten Lebong. Berdasarkan hasil penelitian ditemukan 9 jenis dari 5 famili capung yang terdapat di persawahan Desa Tabeak Kauk. Uji validasi LKPD dari ketiga validator memperoleh nilai rata-rata dengan persentase sebesar 88,1\% (kriteria "sangat layak"). Hasil uji coba LKPD pada 29 peserta didik kelas X mendapatkan persentase ketuntasan klasikal sebesar $82,8 \%$. Hasil uji validasi dan uji coba menunjukan bahwa LKPD yang dikembangkan ini termasuk kategori sangat baik. Berdasarkan hasil validasi dan uji coba tersebut, LKPD berdasarkan keragaman capung di Persawahan Desa Tabeak Kauk Kabupaten Lebong layak digunakan sebagai bahan ajar materi keanekaragaman hayati kelas $\mathrm{X}$ tingkat SMA.
\end{abstract}

Kata Kunci : Capung, Lembar Kerja Peserta Didik, Desa Tabeak Kauk

\begin{abstract}
This research aims to determine the feasibility of Student Worksheets (LKPD) which are developed based on the identification of the types of dragonflies found in the rice fields of Tabeak Kauk Village. This type of research is research and development with the following steps: potential problems, data collection, product design, design validation, design revisions, trials and product revisions. While limited-scale trials were conducted on students of class X of SMAN 3 Lebong Regency. Based on the results of the study found 9 types of 5 dragonfly families found in Tabeak Kauk Village rice fields. The validation test of the LKPD includes material aspects, linguistics, presentation, and graphics to get an average percentage of $88.1 \%$ with the criteria "very feasible" from the three validators. The results of the Student Worksheets (LKPD) trial on 29 students of tenth grade high school got a percentage of classical completeness of $82,8 \%$. The results of validation tests and trials show that the developed Student Worksheets (LKPD) is in a very good category. Based on the results of the validation and trials, the Student Worksheets (LKPD) based on the diversity of dragonflies in Tabeak Kauk Village Rice Field in Lebong Regency is worthy of being used as teaching material for student of tenth grade high school.
\end{abstract}

Keywords: Dragonfly, Student Worksheet, Tabeak Kauk Village 


\section{PENDAHULUAN}

Salah

satu kemampuan

pengelolaan pembelajaran yang diharapkan mampu dilakukan oleh pendidik adalah mengembangkan bahan ajar yang inovatif untuk mempermudah pencapaian tujuan pembelajaran. Pengembangan bahan ajar dapat dilakukan dengan memanfaatkan sumber kekayaan hayati yang terdapat di sekitar sekolah. Bahan ajar yang dapat dikembangkan oleh pendidik salah satunya yaitu lembar kerja peserta didik (LKPD). Komposisi LKPD terdiri dari materi, ringkasan, dan tugas (Prastowo, 2011). Karakteristik dari LKPD yaitu memiliki materi yang ringkas, padat dan teraktual dari sisi informasi. Keunggulan tersebut dapat mempermudah peserta didik untuk memahami materi yang diberikan. Pengembangan LKPD dapat dilakukan dengan cara mengintergrasikan potensi lokal yang ada di sekitar peserta didik.

Salah satu potensi lokal yang ada di Kabupaten Lebong adalah keanekaragaman jenis capung. Hewan capung tergolong ke dalam kelas insekta dengan ukuran sedang sampai besar serta seringkali berwarna menarik. Capung berwarna merah, kuning, hitam kehijaun (Borror et al., 1992 dalam Ansori, 2008). Habitat serangga ini terdiri dari hutan, kebun, sawah, sungai dan danau. Manfaat capung yaitu sebagai bio indikator ekosistem perairan (Ansori, 2008).

Desa Tabeak Kauk potensial dengan area persawahan. Area persawahan sangat cocok untuk menjadi habitat bagi capung untuk hidup. Sebagaimana menurut Herlambang (2016) bahwasanya di kawasan persawahan banyak terdapat suplai makanan bagi capung untuk keberlangsungan hidupnya. Selain itu juga, kawasan persawahan yang dekat dengan sumber perairan tawar dapat mendukung perkembangan larva capung.

Dalam bahasa Yunani, Odonata berarti bergigi. Serangga ini memiliki bentuk tubuh panjang dan ramping, sayap memanjang dan memiliki vena yang banyak serta bermembran. Antara sayap depan dan belakang memiliki bentuk dan ukuran yang hampir sama. Antena pendek seperti bulu yang keras (setaceus). Saat istirahat sayap dikatupkan di atas tubuh atau dibentangkan bersama-sama di atas tubuh (Jumar, 2000).

Capung dikenal sebagai hewan
yang sangat bermanfaat dalam pelestarian lingkungan antara lain sebagai pengontrol perkembangan jentik-jentik nyamuk, pengendali hama wereng, dan sebagai indikator alami mengukur kebersihan air atau dikenal sebagai Bio indikator air bersih. Bio indikator spesies atau kelompok spesies yang fungsi, populasi, atau statusnya dapat mengungkapkan status kualitatif atau kondisi lingkungan (Hanum, 2013).

Adapun Penelitian ini bertujuan untuk mengembangkan Lembar Kerja Peserta Didik (LKPD) berdasarkan identifikasi jenis capung yang terdapat di area persawahan Desa Tabeak Kauk.

\section{METODE}

Penelitian ini merupakan penelitian dan pengembangan (Research and Development) yang mengadopsi dari Sugiyono (2009). Langkah-langkah penelitian R\&D dari Sugiyono (2009) yang akan dilakukan dalam penelitian ini hanya dibatasi sampai 7 tahap penelitian yaitu potensi masalah, pengumpulan data, desain produk, validasi desain, revisi desain, uji coba dan revisi produk. Penelitian dilaksanakan pada Desember 2018 sampai Januari 2019 di SMAN 3 Kabupaten Lebong. Subyek uji coba penelitian ini adalah tiga orang validator, yang terdiri dari dua orang dosen program 
studi Pendidikan Biologi Universitas Bengkulu dan seorang guru biologi SMAN 3 Kabupaten Lebong, serta peserta didik kelas X SMAN 3 Kabupaten Lebong. Teknik pengumpulan data pada penelitian ini menggunakan angket/kuesioner. Adapun angket/kuesioner yang digunakan pada penelitian ini terdiri dari angket validasi yang diberikan ke ahli media, ahli materi dan guru mata pelajaran biologi dan uji coba LKPD yang diberikan ke peserta didik.

Data validasi dan uji coba yang terkumpul dianalisis secara deskriptif kuantitatif. Angka hasil uji yang diperoleh diubah ke dalam persentase kelayakan dengan rumus:

Persentase $=\frac{\text { Jumlah skor lembar validasi }}{\text { Skor maksimal }} \times 100 \%$

(Riduwan, 2015)

Hasil perhitungan persentase validitas kemudian diinterpretasikan dengan menggunakan panduan tabel kriteria interpretasi skor kelayakan LKPD yang dapat dilihat pada Tabel 1. Lembar Kerja Peserta Didik (LKPD) dalam penelitian ini dikatakan layak apabila nilai persentase kelayakan $\geq 61 \%$.

Tabel 1. Interpretasi Skor Uji Validitas

\begin{tabular}{cc}
\hline Skor rata-rata & Kriteria \\
\hline $81-100$ & Sangat Layak \\
$61-80$ & Layak \\
$41-60$ & Cukup Layak \\
$21-40$ & Tidak Layak \\
$0-20$ & Sangat tidak Layak \\
\hline & (Riduwan, 2015)
\end{tabular}

LKPD yang sudah valid dilakukan uji coba lapangan pada siswa. Aspek kinerja siswa terhadap LKPD terdiri dari mengidentifikasi, mengelompokan, menjelaskan, menyimpulkan. Keempat aspek diukur dari hasil kinerja siswa.

\section{HASIL DAN PEMBAHASAN}

Berdasarkan hasil validasi oleh validator (ahli materi, ahli media dan ahli praktisi/guru) maka desain LKPD yang disusun ini dinyatakan dapat dijadikan bahan ajar materi keanekaragaman hayati subtopik keanekaragaman tingkat jenis/spesies. Data hasil validasi LKPD oleh validator dapat dilihat pada Tabel 2 .

Tabel 2. Presentase Validasi LKPD oleh Validator

\begin{tabular}{clcc}
\hline No & \multicolumn{1}{c}{ Validator } & Presentase & Kriteria \\
\hline 1 & Validator 1 (Ahli Materi) & 75 & Layak \\
2 & Validator 2 (Ahli Media) & 96,8 & Sangat Layak \\
3 & Validator 3 (Guru Biologi/Ahli Praktisi) & 92,6 & Sangat Layak
\end{tabular}

Dari hasil validasi oleh tiga orang validator (dua orang dosen Pendidikan Biologi Universitas Bengkulu dan satu orang guru Biologi SMA kelas X SMAN 3 Kabupaten Lebong dapat diketahui bahwa desain LKPD yang disusun ini dinilai sangat layak dengan nilai rata-rata $88,1 \%$. Desain LKPD yang telah divalidasi oleh validator dinilai layak dalam uji validasi logis oleh tiga validator. Namun ada beberapa poin yang perlu diperbaiki sesuai saran validator, antara lain sebagai berikut:
1. Perhatikan tanda baca pada LKPD.

2. Jarak antara Margin dengan batas cover diatur kembali.

3. Perbaiki tata letak foto pada petunjuk pengamatan.

4. Foto perlu direvisi.

5. Penulisan kata latin harus sesuai.

Adapun Perbandingan LKPD sebelum divalidasi dan setelah divalidasi dapat dilihat pada Gambar 1, 2 dan 3 berikut: 


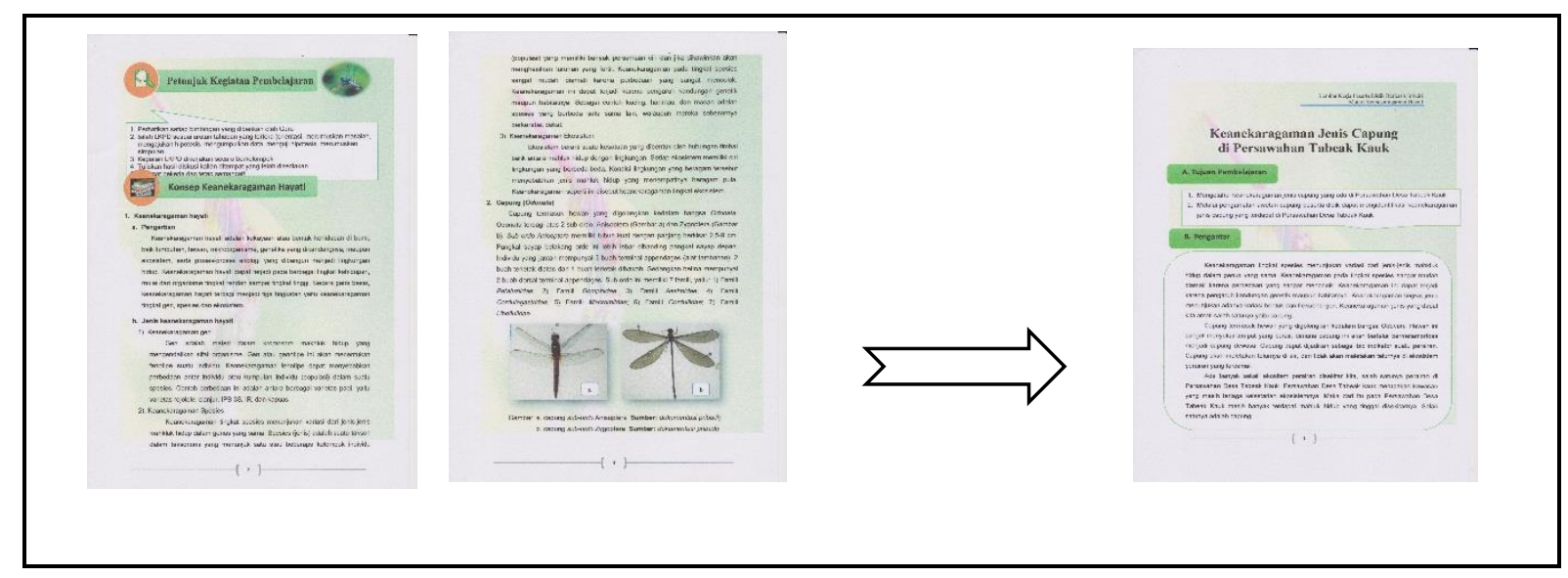

Gambar 1. Perbandingan Ringkasan Materi LKPD sebelum uji coba dan sesudah uji coba

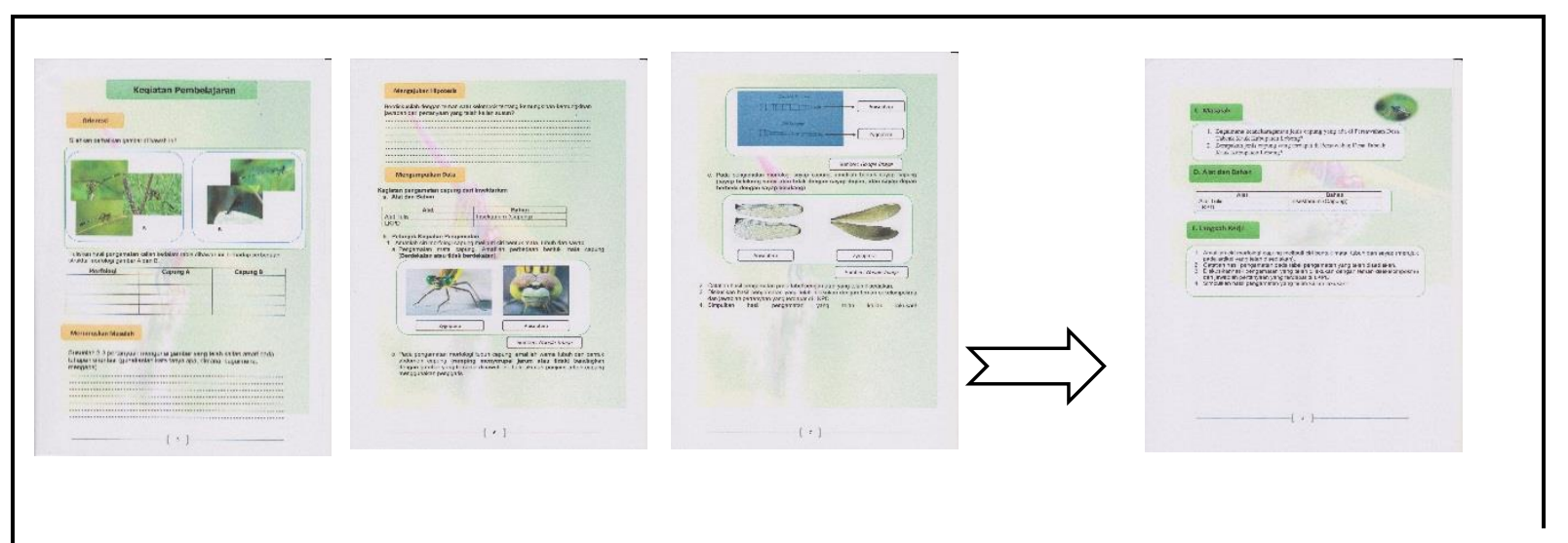

Gambar 2. Perbandingan Rumusan Masalah dan Langkah Kerja LKPD Sebelum Uji Coba dan Sesudah Uji Coba

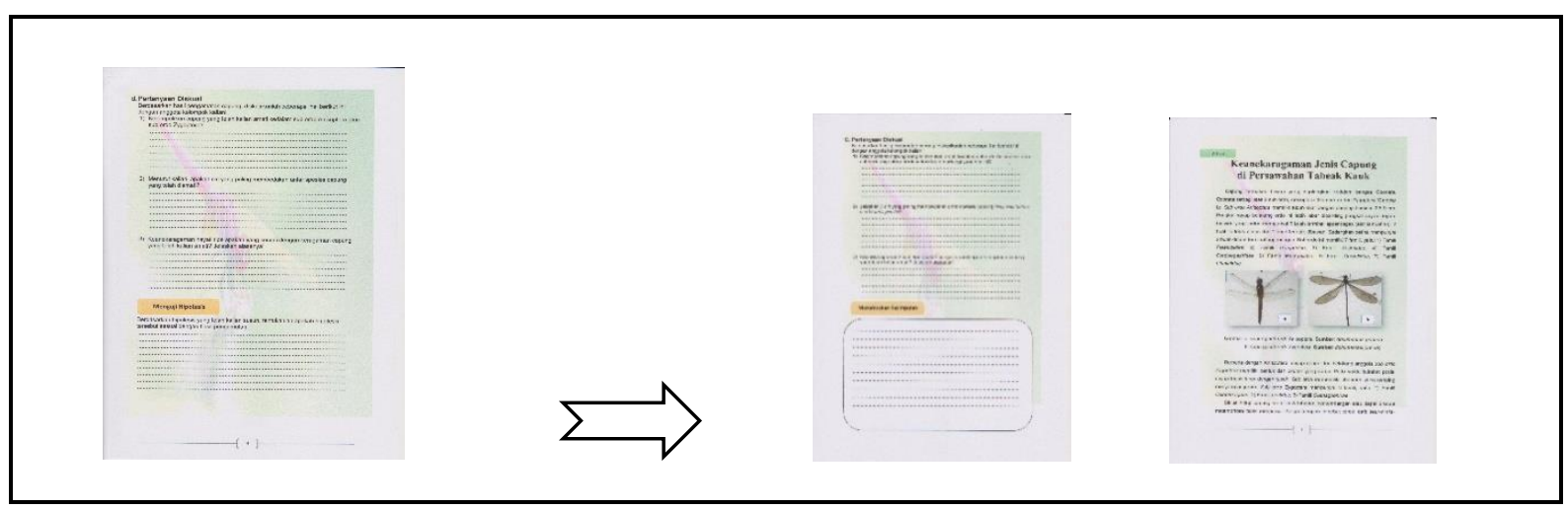

Gambar 3. Perbandingan Soal Diskusi dan Artikel dan Langkah Kerja LKPD Sebelum Uji Coba dan Sesudah Uji Coba

Adapun hasil uji coba validasi empiris menunjukan bahwa LKPD yang dikerjakan secara berkelompok mendapatkan rata-rata $82,8 \%$ dengan kategori "sangat layak", hasil tersebut dapat dilihat pada Tabel 3. 
Tabel 3. Rata-Rata Nilai Per Level Pengerjaan LKPD oleh Peserta Didik

\begin{tabular}{clcc}
\hline No & \multicolumn{1}{c}{ Indikator/Level } & Nilai & Kriteria \\
\hline 1 & Mengidentifikasi & $95,3 \%$ & Sangat Baik \\
2 & Mengelompokan & $83,3 \%$ & Sangat Baik \\
3 & Menjelaskan & $66 \%$ & Baik \\
4 & Menyimpulkan & $88,8 \%$ & Sangat Baik \\
\hline
\end{tabular}

LKPD yang telah disusun dikategorikan "sangat layak" oleh ketiga validator. Hal ini berarti, LKPD yang telah dikembangkan sudah memenuhi unsurunsur LKPD dan layak digunakan sebagai bahan ajar. Uji coba LKPD yang direvisi kepada peserta didik mendapatkan kategori sangat baik dengan nilai rata-rata $82,8 \%$. Menurut Riduwan (2015) jika skor yang diperoleh $>80$ maka termasuk kedalam kriteria sangat baik.

Peningkatan pemahaman peserta didik tertinggi terletak pada indikator mengidentifikasi dengan rata-rata kenaikan sebesar 95,3\%, peningkatan ini diduga karena peserta didik mengidentifikasi ciri morfologi capung secara langsung melalui tabel pengamatan yang terdapat pada LKPD. Sesuai dengan pendapat Rusman (2009) menyatakan bahwa pembelajaran secara langsung atau berinteraksi langsung membuat peserta didik tidak bosan sehingga peserta didik lebih cepat memahami materi yang disampaikan.

Level menyimpulkan juga memperoleh rata-rata tertinggi sebesar $88,8 \%$ dengan kategori sangat baik. Peningkatan ini kemungkinan karena tabel dan soal diskusi pada LKPD cukup menggiring peserta didik untuk menyimpulkan kegiatan pembelajaran. Selain itu tingkat pemahaman anak SMA sudah mampu untuk menganalisis bahan diskusi yang terdapat pada LKPD. Berdasarkan pendapat Purwanto (2011), pemikiran anak usia 15-17 tahun setingkat lebih tinggi dibanding anak usia 7-14 tahun yang biasanya hanya mengingat atau menghafal. Berdasarkan pendapat Purwanto (2011) ini dapat dinyatakan alur berpikir peserta didik level SMA sudah dapat menyimpulkan secara.

Level kemampuan menjelaskan mendapatkan rata-rata persentase terendah yaitu $66 \%$ Level ini mengharuskan peserta didik untuk menjelaskan tingkat keanekaragaman capung manakah yang diamati beserta alasanya. Hal ini diduga karena peserta didik masih sulit untuk membedakan keanekaragaman tingkat spesies dan tingkat gen dikarenakan pada konsep yang tercantum dalam LKPD hanya berisi teori tentang keanekaragaman hayati dan tingkatannya, yang membuat peserta didik sulit untuk memahami maksud dari konsep tersebut.

LKPD yang dikembangkan ini kontekstual dengan lingkungan sekitar sehingga akan membuat peserta didik lebih mengenal lingkungan sekitar mereka. Selain itu LKPD ini juga disusun telah sesuai dengan komponen penyusun LKPD dari Depdikans (2008) yang terdiri dari: judul, kompetensi dasar, tujuan, materi pokok, alat dan bahan, cara kerja, tabel hasil pengamatan, pertanyaan dan kesimpulan.

Keunggulan lain dari LKPD yang telah didesain yaitu LKPD dikembangkan berdasarkan penelitian capung. Pemanfaatan capung sebagai sebagai sumber belajar ini dapat memudahkan peserta didik dalam proses belajar. Karena objek atau materi yang dipelajari sangat dekat dengan mereka. 


\section{PENUTUP}

\section{Simpulan}

Uji validasi menunjukkan kelayakan LKPD yang dikembangkan. Hasil validasi materi menunjukkan bahwa kelayakan materi mendapatkan nilai $75 \%$ (layak) dan kelayakan media mendapatkan nilai $85 \%$ (sangat layak). Penilain dari guru memiliki nilai $85 \%$ (sangat layak). Sehingga dapat disimpulkan bahwa LKPD yang dikembangkan dari hasil identifikasi capung layak digunakan sebagai bahan ajar

\section{Saran}

Sebaiknya penelitian ini dilanjutkan dengan cakupan yang lebih luas dengan melibatkan sampel peserta didik dan sekolah yang lebih banyak untuk menguji keefektivitasan LKPD ini.

\section{DAFTAR PUSTAKA}

Ahmadi, Rulam. 2016. Pengantar Pendidikan Asas dan Filsafat Pendidikan. Yogyakarta: Ar-Ruzz Media.

Ansori, Irwandi. 2008. Keanekaragaan Odonata (Dragonflies) di Beberapa Persawahan Sekitar Bandung Jawa Barat, Jurnal Exacta, Universitas Bengkulu, VI (20) Juli 2019.

Depdiknas. 2008. Panduan Pengembangan Bahan Ajar. Jakarta: Direktorat Pembinaan Sekolah Menengah Atas.

Depdiknas, 2003. UU RI Tahun 2003 Tentang Sisdiknas. Jakarta.

Hanum,S.O., Salma, S., dan Delmi. 2013 .Jenis-Jenis Capung (Odonata) di Kawasan Taman Satwa kandi Kota Sawahlunto, Sumatera Barat.Jurnal
Biologi Universitas Andalas 2(1): 71-76.

Herlambang, A.E.N. 2016. " Struktur Komunitas Capung Di Kawasan Wisata Curug Lawe Benowo Unggaran Barat" Jurnal Bioma. 18 (1) : 70-78.

Jumar. 2000. Entomologi Serangga. Jakarta: PT Rineka Cipta.

Majid, Abdul. 2013. Perencanaan Pembelajaran Mengembangkan Standar Kompetensi Guru. Bandung:PT Remaja Rosdakarya.

Prastowo, A. 2015. Panduan Kreatif Membuat Bahan Ajar Inovatif. Jogjakarta: Diva Press.

Purwanto, A. 2011. Evaluasi Hasil Belajar. Yogyakarta: Pustaka Pelajar.

Riduwan. 2015. Skala Pengukuran Variabel-variabel Penelitian. Bandung: Alfabeta.

Rusman. 2009. Evaluasi Pembelajaran. Bandung: Remaja Rosdakarya.

Sugiyono. 2009. Metode Penelitian Pendidikan (Pendekatan Kuantitatif, Kualitatif dan R\&D). Bandung: Alfabeta.

Yasir, M., Susantini, E., dan Isnawati. 2013. Pengembangan Lembar Kerja Siswa (LKS) Berbasis Stretegi Belajar Metakognitif Untuk Meningkatkan Hasil Belajar Siswa pada Materi Pewarisan Sifat Manusia. Jurnal Bioedu. 2(1): 7782. 